semide and exercise induced asthma: evidence of a role for inhibitory prostanoids. Thorax 1992;47:797-800.

32 O'Connor BJ, Barnes PJ, Chung KF. Inhibition of sodium metabisulphite induced bronchoconstriction by frusemide in asthma: role of cyclooxygenase products. Thorax 1994;49:307-11.

33 Mullol J, Ramis J, Prat J, Rosello-Catafour J, Xaubet A, Piera C, et al. Failure of furosemide to increase production of prostaglandin $\mathrm{E}_{2}$ in human nasal mucosa in vivo. Thorax 1993;48:260-3.

34 Stone KJ, Hart M. Inhibition of renal PGE -9 ketoreductase by diuretics. Prostaglandins 1976;12:197-207.

35 Flavahan NA, Aarhus LL, Rimele TJ, Vanhoutte PM. Respiratory epithelium inhibits bronchial smooth muscle Respiratory epithelium inhibits bron
tone. $\mathcal{A}$ Appl Physiol 1985;58:834-8.

36 Molimard M, Advenier C. Effect of furosemide on bradykinin- and capsaicin-induced contraction of the guineapig trachea. Eur Respir $\mathcal{f}$ 1993;6:434-9.
37 Gerkens JF. Inhibitory effect of furosemide on sympathetic vasoconstrictor responses: dependence on a renal hormone and the vascular endothelium. Clin Exp Pharmacol Physiol 1987;14:371-7.

38 Vanhoutte PM. Epithelium-derived relaxing factor(s) and bronchial reactivity. Am Rev Respir Dis 1988; 138:S24-S30.

39 Holroyde MC. The influence of epithelium on the responsiveness of guinea-pig isolated trachea. $\mathrm{Br} \mathcal{F}$ Pharmacol 1986;87:501-7.

40 Laitinen A. Ultrastructural organisation of intraepithelial nerves in the human airway tract. Thorax 1985; 40:488-92.

41 Laitinen LA, Heino $M$, Laitinen A, Kava T, Haahtela T. Damage of the airway epithelium and bronchial reactivity in patients with asthma. Am Rev Respir Dis 1985; 131:599-906.

\title{
Adventitia
}

\section{A Philadelphia summer}

"The August heat was merciless. From the seventh to the twenty-seventh there were only two cool days. Twice there was rain and afterwards the sun shone through a steamy mist. Those who have lived through Philadelphia summers know these afternoons and would view with compassion the moist faces of the delegates". Thus wrote William Johnson, a Connecticut delegate to the Constitutional Convention which followed the Declaration of Independence two centuries ago.

Things were much the same in August 1976. The sweltering city of the founding fathers was again host to a great variety of groups celebrating the bicentenary of independence. There were conventions of magicians and candlemakers, a Eucharistic congress, national archery and rowing championships - and the fall meeting of the American Physiological Society to which I was to present a paper.

We had one great advantage over the perspiring delegates of 200 years ago - air conditioning - or did we? The first hint that something was amiss was when they switched off the air conditioning at my hotel. I was assured that this was a routine servicing procedure but why in the middle of an August heat wave and who were those heavies snooping around the lobby and corridors? And then the story broke with screaming headlines in the Philadelphia Daily News: dozens of delegates to the convention of the Pennsylvania branch of the American Legion, held in the city two weeks earlier, were being smitten by a mysterious disease from which 19 had already died. Hotel bookings were cancelled and the city, which had invested billions of dollars in the bicentennial celebrations, was facing bankruptcy. Rumours abounded. The veterans of foreign wars accused drug companies of conspiring to release a fatal flu virus in order to promote their vaccine sales. High levels of nickel had been found in the bodies of fatal cases and a left wing group (perhaps communist sailors from a Polish ship moored in the Delaware river) were thought to have injected nickel carbonyl gas into the air conditioning systems of hotels where the legionnaires were staying. Or was there some noxious element in the droppings of those rabbits and doves conjured out of hats at the magicians' convention?

These rumours were not confined to the tabloids and taverns of Philadelphia. Even the Lancet, as late as June 1977, was still promoting the nickel theory and contemplating the possibility that "careless chemists," "mad scientists," "saboteurs," or "criminals" were responsible; or perhaps the nickel carbonyl gas was coming from the garbage cans in which Philadelphians were burning their rubbish because of a garbage collectors' strike? And so the theories proliferated until Joseph McDate noticed a curious red patch on a culture from a guinea pig inoculated with lung tissue from a dead legionnaire. From this he grew Legionella pneumophila, the Gram negative bacillus now known to be the cause of the outbreak.

Of 182 patients with legionella pneumonia, 29 died. The victims included 149 legionnaires, nine Eucharists, two candlemakers, and one magician - but no physiologists. The majority of these had - as indeed had I entered the Bellevue-Stratford hotel or strolled along the adjacent sidewalk on Broad Street. Raised serum titres among the hotel employees suggested long term exposure to the bacillus and a degree of immunity, for only one of the 400 employees contracted the disease. This solitary case was the air conditioner man. Perhaps, like our famous predecessors two centuries ago, we too should have sweated out that Philadelphia summer and eschewed the comforts of modern technology. 